\title{
THE RUSSIAN THEATER IN BERLIN (1919-1923): THE EXPERIENCE OF CULTURAL EXPORTS
}

(C) 2017

\author{
Popov Maxim Evgenievich, master student of History of Russia Department \\ Gorno-Altaisk State University (Gorno-Altaisk, Russian Federation)
}

\begin{abstract}
The paper is devoted to the consideration of Russian theatrical activity in Berlin during 1919-1923, when Berlin was the focus of Russian theater life abroad, and active creative exchange between German and Russian cultures took place in this connection. The problem of exporting Russian art culture to Western countries is of interest for both domestic and foreign researchers. Among the topical problems on this issue, the Russian theater plays an important role. The study of this issue gives an idea of the potential of Russian culture in a different social and cultural environment. In the center of the research is the process of formation and development of Russian theatrical life in the German cultural environment. The author made an attempt to identify and disclose the main artistic directions of the Russian theater in Berlin in 1919-1923 and determine their role in bringing Germany to the achievements of national culture. The work uses materials from the memoirs of contemporaries and periodicals. On the basis of these sources it is shown that the theater played one of the fundamental roles in preserving the Russian cultural community and their cultural appearance on the overseas. Russian theatrical seasons contributed to the West's involvement in the achievements of Russian culture and the establishment of cultural and artistic ties between Germany and Soviet Russia. Thus, the activities of the Russian émigré and touring Russian theater in Berlin in 1919-1923 reflected the high potential of Russian culture in the conditions of a foreign social environment.

Keywords: Russian émigré theater; tour theater; Berlin; Germany; performance; staging; chamber theater; «Blue bird»; «Vanka-Vstanka»; «Kikimora»; Moscow Art Theater of Stanislavsky; Moscow Artistic Mobile Theater; Russian art culture.
\end{abstract}

УДК 93/94: 793 (470.56)

Статья поступила в редакцию 01.10.2017

\section{ОРЕНБУРГ КАК СТОЛИЦА АВТОНОМНОГО КАЗАХСТАНА (1920-1925 ГГ.): ПРИЧИНЫ ВЫБОРА И ПОПЫТКИ ПОИСКА АЛЬТЕРНАТИВ}

(C) 2017

\author{
Аканов Куаныш Газизович, докторант кафедры Евразийских исследований \\ Евразийский национальный университет им. Л.Н. Гумилёва (2. Астана, Республика Казахстан)
}

Аннотащия. В статье рассматривается история утверждения Оренбурга в качестве столицы, образованной 26 августа 1920 г. Киргизской (Казахской) Автономной Советской Социалистической Республики (КАССР), а также история присоединения города и некоторых районов губернии к Казахстану. Исследуются причины выбора Оренбурга как административного центра республики и возможные предлагаемые альтернативы. Проводится историографический анализ публикаций казахстанских и российских исследователей по обозначенной теме. Среди объективных причин выбора Оренбурга в качестве столицы названы следующие: важность Оренбурга для тогдашней Киргизской Республики как города с развитой инфраструктурой и промышленностью, а также культурным и экономическим потенциалом; наличие достаточно крепкой прослойки рабочих, на которых планировало опереться руководство РСФСР в ходе процесса образования автономии и налаживания контроля; попытка сделать город центральным звеном политики движения на сближение с азиатскими и тюркскими народами; урегулирование территориальных споров о вопросе принадлежности Оренбурга; временность столичного статуса Оренбурга ввиду географической отдаленности города от других регионов автономии и малого представительства титульного казахского этноса. В ходе исследования использованы ранее не введенные в научный оборот документы Государственного архива Оренбургской области. Выявлены значение и роль Оренбурга в становлении казахской государственности в XX веке.

Ключевые слова: Оренбург; столица; Оренбургская губерния; Киргизская Автономная Советская Социалистическая Республика; Российская Советская Федеративная Социалистическая Республика; Гражданская война; декреты Советской власти; Киргизская (Казахская) автономия; казахская государственность в XX веке; история Казахстана.

Российский город Оренбург внес свой неотъемлемый вклад в историю формирования казахской государственности XX века. В 1920-1925 гг. этот город был столицей Киргизской (Казахской) Автономной Советской Социалистической Республики (КАССР), которая была образована в составе Российской Советской Федеративной Социалистической Республики (РСФСР).

Об истории основания КАССР подробно свидетельствует документ «История Казахстана и его природные богатства» (1924-1925), хранящийся в Государственном архиве Оренбургской области. Соглас- но ему, начало создания республики было «положено декретом Совета Народных Комиссаров РСФСР, изданным 10 июля 1919 г., распубликованным в № 155 «Известия» ВЦИКа (Всероссийского Центрального Исполнительного Комитета - прим. авт.) от 17 июля 1919 года» [1, л. 1].

Согласно декрету, вплоть до созыва запланированного всеобщего Киргизского Съезда и объявления автономии Киргизского Края в целях руководства создавался Военно-Революционный Комитет, в котором сконцентрировались функции гражданского управления автономии. Революционный комитет 
(Ревком) состоял из 7 членов, назначаемые Центральной властью Российской Республики. До определения территории Киргизского края соглашением Туркестанской республики, Киргизского съезда и Центральной Советской власти в подчинение Ревкома входили: киргизская территория Астраханской губернии и области: Уральская, Тургайская, Акмолинская и Семипалатинская [2, с. 12]. Исследователь Д.А. Аманжолова уточняет, что заселенная казахами часть Астраханской губернии называлась Букеевской Ордой [3, с. 354].

Следуя упоминаемому выше архивному документу, окончательно вопрос об автономии КАССР был разрешен декретом СНК и РСФСР от 26 августа 1920 г., а также дополнением к нему, которое было опубликовано в № 216 газеты «Известия» ВЦИКа от 22 сентября 1920 г., выпущенным в развитие уже указанного декрета от 10 июля 1919 года. В документе даются сведения, что Автономная Киргизская Социалистическая Советская Республика была образована как часть РСФСР [1, л. 2]

Тексты декретов даются в сборнике документов и материалов «Столицы Казахстана». По декрету от 26 августа 1920 г. в состав КАССР включались области: Семипалатинская - уезды: Павлодарский, Семипалатинский, Усть-Каменогорский, Каркаралинский; Акмолинская - уезды: Атбасарский, Акмолинский, Кокчетавский, Петропавловский и часть Омского уезда; Тургайская - уезды: Кустанайский, Актюбинский, Иргизский, Тургайский; Уральская - Уральский, Лбищенский, Темирский и Гурьевский; Мангышлакский уезд Закаспийской области - 4-ая и 5-ая Адаевские волости Красноводского уезда той же области; из Астраханской губернии - Синеморская волость, Букеевская Орда, территории 1-го и 2-го Приморских округов, а также Сафроновская, Ганюшинская и Ново-Николаевская области [4, с. 27]. Согласно декрету от 22 сентября 1920 г. в республику вошли г. Оренбург, а также Оренбургско-Покровский, Краснохолмский, Илецкий, Шарлыкский, Жаевский и Петровский районы Оренбургской губернии [5, с. 239]. А г. Оренбург стал столицей республики [6, с. 12].

4 октября 1920 г. в Оренбурге председателем Кирревкома В.А. Радус-Зеньковичем был открыт Первый Учредительный Всекиргизский съезд Рабочих, Крестьянских, Казачьих и Красноармейских депутатов, созванный в силу декрета от 26 августа 1920 года. В работе съезда участвовало 273 делегата: коммунисты - 197, сочувствующие - 4, беспартийные - 72. По национальному признаку - казахов было 126 чел., русских - 129, татар - 14, башкир - 2, латышей -1 , евреев -1 . В президиум съезда помимо уже упоминавшегося Радус-Зеньковича вошли: Мендешев, Авдеев, Досов, Акулов, Струппе, Байтурсынов и Мартынов. По принятому на съезде положению, высшей властью в республике считался Всекиргизский Съезд Советов [1, л. 2]. Были также избраны такие рабочие органы, как Центральный Исполнительный Комитет (ЦИК), председателем которого был назначен С.М. Мендешев, и Совет Народных Комиссаров (СНК) республики под председательством самого Радуса-Зеньковича. Съезд принял «Декларацию прав трудящихся Киргизской (Казахской) АССР», которая законодательно закрепила создание республики [7, с. 211-212].
Интересно, что наименование «Киргизская АССР» просуществовало до апреля 1925 г., когда 19 апреля 1925 г. V съезд Советов республики принял решение о восстановлении исторически правильного названия казахского народа и о переименовании Киргизской республики в Казахскую АССР, а 15 июня 1925 г. Президиум ВЦИК принял постановление о переименовании [5, с. 239].

В настоящее время исследователями активно обсуждаются причины выбора Оренбурга столицей Киргизской автономии. Некоторые казахстанские авторы придерживаются точки зрения о том, что при принятии решения руководством РСФСР не учитывались интересы самой автономной республики и предложения национальных лидеров [8, с. 5-6]. Составители сборника «Столицы Казахстана» считают основной причиной наличие крупной прослойки рабочего класса, сосредоточенного в Оренбурге, который советское руководство намеревалось использовать для укрепления своей власти среди казахов. По данным авторов сборника, в городе тогда проживало 100 тыс. человек [9, с. 8]. Несколько другие данные называет авторитетный историк Л.И. Футорянский, указывающий, что в Оренбурге насчитывалось более 100 тыс. чел., тогда как, к примеру, в Кустанае всего 22 тыс. чел., а в Актюбинске - 11 тыс. чел. В то время город занимал 28 место по количеству жителей и считался одним из крупнейших городов тогдашней России. Футорянский более основательно доказывает тезис по планированию большевиков на первых поpax опереться на рабочих, опираясь на статистические данные Всероссийской переписи населения. По численности служащих фабрик и заводов Оренбургская губерния занимало 15 место по всей России. В самом Оренбурге численность рабочих составляла 9 542 чел., в то время как в Акмолинске около 4 тыс., в Семипалатинске - 4800 , в Уральской губернии 4,4 тыс., в Кустанае - 1560 [10]. В публикации материалов научной конференции, посвященной 250-летию Оренбурга, Футорянский уточняет, что, по данным за 1918 г., в Оренбурге проживало 108 тыс. чел., помимо 28-го места по численности по всей России, город также занял 1-е место на Урале. В начале ХХ века здесь работало около 12 тыс. рабочих. В 1897 г. здесь был организован первый марксистский кружок, в 1905 - Оренбургская группа Российской социал-демократической рабочей партии (РСДРП), в которой уже спустя год насчитывалось около 200 чел., в проходящих в городе стачках участвовало $29,4 \%$ рабочих [11, с. 7-8]. По мнению ученого, город был не только одним из крупнейших городов тогдашней России, но и важным промышленным и культурным центром, который бы мог способствовать развитию всего Казахстана [10].

Справедливость мнения о важности Оренбурга для Киргизии подтверждает Е. Артамонова, которая ссылается на резолюцию 3-го Орского уездного съезда Советов 15-21 августа 1920 года: «...Оренбургская губерния имеет громадное производственное и культурное значение для народов Востока и, в частности, киргизского края, вследствие чего население имеет непосредственное экономическое и политическое тяготение к Оренбургу как к культурному и промышленному центру. 3-й Уездный съезд Советов рабоче-крестьянских, казачьих и киргизских 
депутатов, решение Оренбургской конференции Советов и киргизского краевого Ревкома о слиянии Оренбургской губернии с Киркраем находит единственно правильным разрешением вопроса...» [12, c. 21].

Немного в другом русле свою мысль развивает известный ученый Г.Г. Косач, который считает, что советские деятели Оренбурга своими действиями и выступлениями пытались возродить некоторые символы и мифы прошлого. В их представлениях город был «центральным звеном «государственной» модели организации регионального пространства и оплотом движения на Восток...обрамленного идеей пролетарской трансформации мира» [13, с. 88-89]. В подтверждение своего тезиса Косач приводит выступления секретаря губернского комитета партии И.С. Акулова, тексты которого и резолюции были найдены исследователем в документах Центра документации новейшей истории Оренбургской области (ЦДНИОО). «...Оренбург как крупный центр является связующим звеном Советской России с Туркестаном и Средней Азией... В Оренбурге решали «государственную» задачу, укрепляя влияние рабочекрестьянской власти...среди народностей, населяющих эти области...Оренбург является местом скрещивания интересов разных национальностей» [13, с. 88].

Однако только ли Киргизия нуждалась в объединении с Оренбургом? В упоминавшемся выше архиве хранится выпуск 20-го номера газеты «Известия Киргизского Края» официального органа Военнореволюционного комитета (ВРК) по управлению Киргизским краем, датирующийся субботой 5 июня 1920 года. В статье «Объединение Оренбургской губернии с Киргизией» публиковалась резолюция по вопросу объединения Оренбургской губернии с Киргизской Республикой состоявшегося 3 июня в здании Оренбургского губисполкома заседания ответственных работников ВРК, организационного бюро Киркрая, Оренбургских органов власти: губкома, губисполкома, горисполкома и др. Обратим внимание на формулировки текста документа: «Исходя из соображения, что Оренбургская губерния после выделения Челябинской губернии и присоединения части ее территории к Башкирской республике оказалась в настоящих ее границах в положении полной невозможности существования как самостоятельной административной единицы, и учитывая сильную экономическую зависимость ее промышленности от Киргизского края и Башкирии ... признавая громадное культурное и промышленное значение Оренбурга для Киргизии и то, что Оренбург является единственным пролетарским центром для средней Киргизии - совещание ответственных Оренбургских организаций по соглашению с военно-революционным комитетом по управлению киргизским краем постановило признать необходимым слить Оренбургскую губернию с Киргизской республикой» [14, л. 177]. Документ дает понять, что необходимость в слиянии была обоюдной для обоих обсуждаемых нами субъектов, чтобы помочь другу выстоять в то трудное время, когда изматывающая Гражданская война близилась к завершению, а руководство РСФСР столкнулось с нелегкими задачами территориального деления земель между возникающими автономными республиками и губерниями.
Среди казахстанских исследователей по теме выдвижения Оренбурга в качестве столицы автономного Казахстана актуален тезис об изначальной временности статуса города. Данного мнения придерживались авторы приводимых выше библиографического указателя и сборника документов и материалов, выпущенных под одинаковым названием «Столицы Казахстана». На взгляд составителей указателя Р.М. Абишевой, А.Ш. Сайдембаевой и А.К. Рахимовой, Оренбург оставался «русским» и территориально далеким от других регионов автономии городом, в котором было невозможно решить многие «национальные» проблемы [8, с. 5-6]. Авторский коллектив сборника документов под руководством к.и.н. Р.Х. Сариевой мотивируют свою позицию следующими тезисами: 1) малочисленность проживающего в Оренбургской губернии казахского этноса; 2) географическая отдаленность Оренбурга; 3) опасения Советской власти перед возможным объединением соседних «Татарстана, Башкортостана, Казахстана, республик Средней Азии с выходом на Турцию» [9, c. 8]. Однако отметим, что если мотивация географического местоположения Оренбурга понятна сразу, то остальные тезисы не подтверждаются никакими доказательствами. Не приводятся статистические данные в поддержку мнения о малочисленности казахов на тот момент, а также сведения, подкрепляющие позицию по последнему мнению о возможных страхах Советского руководства перед возможностью указанного союза и о самой его вероятности.

Что же касается «русскости» Оренбурга, то напомним, что в Оренбурге проходили два Общеказахских съезда под эгидой движения «Алаш», было сформировано правительство «Алаш-Орда» и провозглашена автономия, выпускалась национальная газета «Казах», в местных газетах выходили статьи представителей казахской интеллигенции, к примеру И. Алтынсарина, печатались издания на казахском языке. Последнее подтверждает и Д.В. Шаргалов, приводя сведения о том, что типография Б. Бреслина в конце XIX в. выпустила 20 изданий, среди которых были и казахскоязычные [15, с. 333]. В.В. Амелин приводит сведения о том, что дети богатых казахов обучались в Неплюевском военном училище, в 1847 году была открыта казахская фельдшерская школа, а в 1890 г. - русско-киргизская (казахская) учительская школа [16, с. 4]. По данным Т.А. Камсковой, в 1850 г. в Оренбурге начала действовать первая школа для киргизских детей, в которой обучался И. Алтынсарин, закончивший ее в 1857 г. [17, с. 32].

Более подробно вопрос о причинах передачи Оренбурга и назначения города центром Киргизской Республики исследует д.и.н. Д.А. Аманжолова. В своих работах ученый детально рассматривает многие возникающие тезисы. Так, говоря о малочисленности проживающего в Оренбуржье казахского этноса, исследователь приводит данные переписи 1897 года, когда в Оренбургской губернии насчитывалось 1600145 чел., из них казахи составляли $0,31 \%$ [18, с. 56]. Добавим, что Н.Е. Бекмаханова указывает, что во всем тогдашнем Казахстане и Киргизии, согласно переписи населения 1897 г., проживало 4932 тыс. чел. Из них казахов насчитывалось 2449,1 тыс. чел. [19, с. 63, 138]. Что касается тезиса об игнорировании национальных интересов автономии при включении Оренбурга в состав автономной 
республики, то Аманжолова отмечает, что присоединению города предшествовало ряд важных событий и заседаний. В сентябре 1919 г. силы Туркестанского фронта вытеснили войска белых из Оренбургской губернии и Тургайской области. 10 сентября 1919 г. состоялось совещание Оренбургского ВРК с ответственными работниками КирВРК и представителями военного руководства, где обсуждался вопрос о присоединении Оренбурга к Казахстану. Председатель КирВРК Пестковский выразил мнение Центра в поддержку присоединения, однако против его позиции выступили представители Оренбурга А.А. Коростелев, И.Д. Мартынов и др., которые предлагали включить в Оренбургскую губернию Уральскую область и Актюбинский уезд Акмолинской области. Не поддерживали точку зрения Центра члены КирВРК А. Байтурсынов, С. Мендешев и М. Тунганчин. Байтурсынов видел в этом решении «попытку лишить автономию самостоятельности» [3, с. 355]. Возникшие разногласия требовали вмешательства Центра. 20 сентября состоялось совещание Оренбургского губкома партии, губисполкома, высшего командования Туркфронта и 1-й армии с участием председателя ВЦИК М.И. Калинина, где представители Оренбурга признали свой протест ошибочным. Однако участвовавший в работе заседания А. Байтурсынов отказался от голосования и указал на неправомочность совещания. Итогами заседания стало поручение председателю Оренбургского губкома РКП(б) И.А. Акулову подготовить доклад о положении Киргизии и определение г. Оренбурга как административного центра планируемой республики. 15 декабря 1919 г. состоялось совещание руководства ВЦИК и пограничных губерний, председателем которого был М.И. Калинин. Итогом заседания стало принятие решения о передаче в административную комиссию при ВЦИК вопросов о принадлежности Оренбурга и о границах Киргизии и Башкирии. Весной 1920 г. Центру удалось переубедить противников статуса Оренбурга как центра автономной республики, а 4 июня 1920 года Киргизский ВРК «принял постановление о проведении в жизнь включения Оренбургской губернии в состав автономии» [20, с. $337-$ 342]. Постановление принималось «ввиду согласия Оренбургского губисполкома на вхождение в состав Киргизии», в целях проведения данного слияния была избрана комиссия в составе Айтиева, Кулакова, Бегимбетова [21, с. 24]. Продолжая мысль Аманжоловой, можно сделать вывод, что, несмотря на то, что стремление Центра и мнения казахских лидеров о присоединении Оренбурга вначале испытывали разногласия, руководству РСФСР в конечном счете удалось убедить оппонентов в правильности своей позиции. Таким образом, речь идет больше о принятии согласованного решения, чем о полном игнорировании.

Со своей стороны Д.А. Аманжолова указывает, что Оренбург считался наиболее удобным для РСФСР вариантом в качестве столицы Киркрая по следующим причинам: «1) Такое решение проблемы отрывало ненадежную, с точки зрения Центра, национальную элиту от непосредственного общения с массами и облегчало контроль над ней... 2) Столица должна была располагаться в городе, имевшем необходимую инфраструктуру, кадровый, организационный, финансовый, производственный, материально- технический потенциал...3) Присоединение Оренбургской губернии к казахской автономии подрывало бы устои казачьей самостоятельности. 4) Учитывалось, что до революции Оренбург был своеобразным центром активности татарских, башкирских и казахских деятелей» [22, р. 119]. Таким образом, передав г. Оренбург Казахстану, Центр надеялся закрыть вопрос о претензиях башкирских и татарских национальных лидеров на вхождение города в свою сферу влияния. В подтверждение тезиса о претензиях Аманжолова приводит пример члена Башкирского ВРК А.-3. Валидова, который в записке Ленину предлагал сделать из Оренбурга «крепкий культурнопросветительский и экономический центр», включив город вместе с губернией в состав задумываемой им «объединенной Киргизо-Башкирии». Но Политбюро ЦИК это предложение отклонил [20, с. 339-341]. Что касается другого тезиса, то, действительно, на территории тогдашнего Казахстана городов, равных Оренбургу в промышленном и инфраструктурном отношении, практически не было. Исключением, по мнению Аманжоловой, мог быть только Семипалатинск, предлагавшийся деятелями «Алаш». Но этот вариант имел для Советского правительства несколько больших минусов: во-первых, к моменту начала обсуждения вопроса о столице город еще не контролировался большевиками, а во-вторых, Семипалатинск был центром автономии Алаш, где преобладали сторонники движения «Алаш», в начале войны поддерживавшего противоположную сторону. Да и сам Оренбург, по сравнению с другими городами планируемой автономии, в сознании большевистского руководства представлялся «символом пролетарского авангарда» для ее населения [3, с. 356-359]. Добавим, что только 1 декабря 1919 года в Семипалатинске началось восстание против белых, поддержанное силами «Алаш» и силами местного подполья [23, c. 238]. Успешному ходу восстания способствовали партизаны и части 26-й стрелковой дивизии. 10 декабря 1919 г. Красная Армия вступила в город [24, c. 209]. Тогда как вопрос о столице автономии, как мы помним, начал обсуждаться в сентябре 1919 года.

Кстати, Д.А. Аманжолова уточняет, что мнение о временности назначения города центром создаваемой киргизской автономии прозвучало в выступлении А. Ермекова на совещании 9-10 августа 1920 года. «При установлении границ Киргизии надо будет принять во внимание этнические, экономические и культурные особенности во всем крае...Культурные и экономические центры ... находятся на окраинах территории Киргизии, на которые претендуют смежные областные образования. Без этих центров южные области будут обречены на экономический, хозяйственный и экономическо-культурный голод и вымирание. Исходя из этих соображений, необходимо временно установить указанные границы Автономной Киргизии. Центром временно намечается Оренбург» [3, с. 361]. Данное совещание было очень важным, так как именно на нем решался вопрос о территориях и границах Киргизской автономной республики. Большую роль в нем сыграли как примкнувшие к большевикам бывшие участники движения «Алаш», так и казахские советские деятели. Однако так как указанные вопросы не входят в предмет обсуждения данной статьи, то для их рассмотрения мы предлагаем обратиться к работам Д.А. Аманжо- 
ловой, приводящимся в библиографическом списке литературы. Мы же продолжим исследование хода исторического процесса о присоединении Оренбурга к Киргизии. В ГАОО были также найдены несколько документов дела №91, относящегося к Описи 1, фонда Р-1, которые помогли более детально проследить исследуемый вопрос.

5 июня 1920 г. в газете «Известия Киргизского Края» была опубликована резолюция заседания, состоявшегося 3 июня в здании Оренбургского горисполкома, по вопросу объединения Оренбургской губернии с Киргизской республикой. Согласно документу «предполагалось, что вопрос об объединении должен был быть разрешен на совещаний при ВЦИК по установлению границ Кирреспублики, назначенном на 1 августа 1920 года. Но так как был упущен период заготовок и в связи с опасениями отсутствия налаженного управления в Тургайской области и экономических организаций, было признано необходимым немедленное объединение Оренбургских органов с ВРК Киркрая» [14, л. 177].

16 июня 1920 года был опубликован Приказ Революционного Комитета Киргизского Края и Оренбургского Губернского Исполнительного Комитета Советов, который постановил: «1) Объединить Оренбургский и Тургайский Продовольственные Комиссариаты в один продовольственный орган, распространяющий свои действия на территории Оренбургской губернии и Тургайской области, под названием: Оренбургско-Тургайский Продовольственный Комиссариат; 2) начало функционирования названного объединенного Продовольственного Органа считать с 16 июня 1920 г. ...» [14, л. 174].

7 июля 1920 года вышло Постановление ВоенноРеволюционнаго комитета по управлению Киргизским Краем Оренбургского губернского исполнительного комитета Советов, основные решения которого звучали следующим образом: «На основании ст. 11 конституции РСФСР и Постановления Оренбургской Конференции Советов от 1 июля 1920 года о присоединении Оренбургской губернии к имеющей быть образованной Киргизской Республике, Военно-Революционный Комитет по Управлению Киргизским Краем и Оренбургский Губернский Исполнительный Комитет ПОСТАНОВИЛ: 1) В целях наискорейшего создания органов Советской Власти, организации снабжения населения и сбора сырья в Тургайской губернии, не предрешая вопроса о границах этих губернии, временно до окончательного разрешения вопроса о внутреннем административном делении Киргизской Республики Оренбургскую и Тургайскую губернии слить в Оренбургско-Тургайскую, в состав которой входят: Тургайский, Иргизский, Актюбинский уезды Тургайской области, Адамовский район Кустанайского уезда, Тургайской области и Темирский уезд, Уральской области и из Оренбургской губернии в ее настоящих границах районы: Оренбургский, Покровский, Краснохолмский, Илецкий, Шарлыкский, Исаевский, Петровский. 2) Общее направление деятельности ОренбургскоТургайского Губернского исполкома на общих основаниях принадлежит Военревкому Киркрая, который пополняется 2-мя членами из числа ответственных Оренбургских работников... [14, л. 175].

Аманжолова сообщает, что 12 августа 1920 года состоялось совещание под председательством уже самого В.И. Ленина, а 14 августа заседание коллегии Наркомнаца одобрило декрет о республике. 16 числа проект был поддержан административной комиссией при Президиуме ВЦИК, а 17 и 24 августа - СНК РСФСР. 26 августа 1920 г. Декрет вступил в силу. К автономии отошли Оренбург, Уральск, Кустанай и Порт-Александровск. Однако в опубликованном в «Известиях ВЦИК» декрете об образовании КАССР Оренбургская губерния отсутствовала, на что обратило внимание представительство КирВРК и 3 сентября направило в СНК РСФСР просьбу о принятии мер. 20 сентября 1920 г. вышло постановление ВЦИК о включении в состав КАССР Оренбурга и некоторых районов Оренбургской губернии [20, с. 346-347].

Оренбург пробыл в составе Киргизской республики недолго. В январе-феврале 1925 г. было принято решение о переносе столицы из г. Оренбурга в г. Ак-Мечеть [9, с. 33-34]. 2 апреля 1925 года Политбюро ЦК РКП(б) поручило Президиуму ВЦИК создать комиссию «по размежеванию Оренбургской губернии и КАССР», а 6 апреля решением ВЦИК Оренбургская губерния вышла из состава КАССР [20, с. 346-347]. Таким образом, подводя итоги исследования, можно сделать следующие выводы.

Исследование вопроса присоединения Оренбурга к Киргизской республике и назначения города столицей автономии является актуальным и интересующим ученых как в Казахстане, так и в России. По вопросу причин принятия решения о выдвижении Оренбурга в качестве столицы наиболее обоснованными, на наш взгляд, выглядят такие мнения:

- важность для только что образованной Киргизской Республики Оренбурга как города с развитой инфраструктурой и промышленностью, а также культурным и экономическим потенциалом, особенно если учесть, что процесс образования происходил сразу после окончания Гражданской войны;

- наличие достаточно крепкой прослойки рабочих, на которых планировало опереться руководство РСФСР в ходе процесса образования автономии и налаживания контроля над ней;

- попытка сделать город центральным звеном «"государственной" модели организации регионального пространства и оплотом движения на Восток», которое было актуально для большевиков в исследуемый период;

- урегулирование территориальных споров о принадлежности Оренбурга;

- временность принадлежности Оренбурга Киргизии, ввиду географической отдаленности города от других регионов автономии и малого количества представительства казахского этноса.

В целом Оренбург сыграл важную роль в создании Казахской автономии и оставил свой неотъемлемый след в истории становления казахской государственности XX века.

\section{СПИСОК ЛИТЕРАТУРЫ:}

1. Государственный архив Оренбургской области (далее - ГАОО). Ф. Р-454. Оп. 1. Д. 18-А.

2. Декрет Совнаркома РСФСР «О Революционном комитете по управлению Киргизским краем». 10 июля 1919 г. // Столицы Казахстана. Сборник документов и материалов. Астана, 2008. 278 с.

3. Аманжолова Д.А. На изломе. Алаш в этнополитической истории Казахстана. Алматы: издательский дом «Таймас», 2009. 412 с. 
4. № 9. Декрет ВЦИК и СНК «Об образовании Автономной Киргизской Социалистической Советской Республики». 26 августа 1920 г. // Столицы Казахстана. Сборник документов и материалов. Астана, 2008. C. 27-32.

5. Примечания // Столицы Казахстана. Сборник документов и материалов. Астана, 2008. С. 238-240.

6. Оренбург // Столицы Казахстана. Сборник документов и материалов. Астана, 2008. С. 12.

7. Елагин А. Образование Казахской АССР // Энциклопедический справочник: «Казахская Советская Социалистическая Республика» / гл. ред. М.К. Козыбаев. Алма-Ата: Главная редакция Казахской Советской Энциклопедии, 1981. С. 211-212.

8. Столицы Казахстана: библиографический указатель / Нац. б-ка РК; сост. Р.М. Абишева, А.Ш. Сайдембаева; ред. А.К. Рахимова. Алматы, 2011. С. 5-6.

9. Столицы Казахстана. Сборник документов и материалов. Астана, 2008. 278 с.

10. Футорянский Л.И. Оренбург - столица Казахстана [Электронный ресурс] // Интернет-проект «Заметки на полях». Опубликовано: декабрь, 2006 // http://his95.narod.ru/oren/istor_9_4.htm.

11. Футорянский Л.И. Оренбург (1743-1993) // Оренбургу - 250 лет: программа и материалы науч. конф., посв. 250-летию города. Оренбург, 1993. С. 7-8.

12. Артамонова Е. Оренбург - столица Казахстана // Оренбуржье. 10 января 2002 года. № 5-6. С. 21.

13. Косач Г.Г. Оренбург и Башкирская автономия: «государственный» город в начале советской эпохи // Восьмые Большаковские чтения. Оренбургский край как историко-культурный феномен: сборник статей междунар. науч.-практ. конф. / науч. ред. С.В. Любичанковский. Оренбург: Изд-во ОГПУ, 2016. C. 88-93.

14. ГАОО. Ф. Р-1. Оп. 1. Д. 91.

15. Шаргалов Д.В. Развитие частного типографского дела на Южном Урале в 1847-1917 гг. // Восьмые Большаковские чтения. Оренбургский край как историко-культурный феномен: сборник статей междунар. науч.-практ. конф. / науч. ред. С.В. Любичанковский. Оренбург: Изд-во ОГПУ, 2016. С. 332-341.

\section{ORENBURG AS THE CAPITAL OF AUTONOMOUS KAZAKHSTAN (1920-1925): THE REASONS OF CHOICE AND ATTEMPTS OF SEARCH FOR ALTERNATIVES}

(C) 2017
16. Амелин В.В. Казахи Оренбуржья // Казахи Южного Урала: история и современность: сборник статей и тезисов / под ред. А.В. Федоровой. Оренбург, 1995. С. 3-6.

17. Камскова Т.А. Из истории просвещения казахов Оренбургской губернии в XIX в. // Казахи Южного Урала: история и современность: сборник статей и тезисов / под ред. А.В. Федоровой. Оренбург, 1995. С. 31-35.

18. Аманжолова Д.А. Оренбург в истории столиц Казахстана / Д.А. Киселева-Аманжолова // От столицы - к столице: мат-лы научной экспедиции, посв. 550-летию Казахского ханства. 2015. С. 56-78.

19. Бекмаханова Н.Е. Многонациональное население Казахстана и Киргизии в эпоху капитализма (60-е годы ХІХ в. - 1917 г.). М.: Наука, 1986. С. 63, 138.

20. Аманжолова Д.А. Алаш: исторический смысл демократического выбора / Историческая монография. Алматы: Изд. дом «Таймас». 2013. 400 с.

21. № 6. Постановление Кирвоенревкома о вхождении Оренбургской губернии в состав Казахстана. 4 июня 1920 г. // Столицы Казахстана. Сборник документов и материалов. Астана, 2008. С. 24.

22. Аманжолова Д.А. Казахская автономия: от замысла националов к самоопределению по-советски // Acta Slavica Iaponica, Tomus 21. P. 115-143.

23. Григорьев В.К. Алихан Букейханов. История Казахстана в лицах (Политические портреты). Вып. 1: учебное пособие / под ред. В.К. Григорьева и А.К. Кусаинова. Акмола, 1999. С. 16-40.

24. Байгабылов Н. Казахстан в годы иностранной интервенции и гражданской войны // Энциклопедический справочник «Казахская Советская Социалистическая Республика» / гл. ред. М.К. Козыбаев. Алма-Ата: Главная редакция Казахской Советской Энциклопедии, 1981. С. 203-210.

Статья публикуется при поддержке гранта Российского фонда фундаментальных исследовании (РФФИ) проекта № 17-39-50001 на тему: «Оренбург в истории становления государственности Казахстана».

\section{Akanov Kuanysh Gazizovich, PhD student of Eurasian Researches Department} L.N. Gumilyov Eurasian National University (Astana, Republic of Kazakhstan)

Abstract. The paper considers the history of approval of Orenburg city as the capital of Kirgiz (Kazakh) Autonomous Socialist Soviet Republic (KASSR) which was formed by the decree from 26 of August, 1920, as well as the history accession of the city and some district of province to Kazakhstan. The reasons of choice of Orenburg as administrative center of Kirgiz Republic and possible proposed alternatives are researched. The author analyses publications of Kazakhstan and Russian scientists on the indicated theme. Among the objective reasons of choice of Orenburg as the capital, the author names the following ones: the importance of Orenburg for Kirgiz Republic of that time, as a city with developed infrastructure and industry, as well as cultural and economic potential; the presence of sufficiently strong stratum workers,; attempt to make the city a central core of politics and become closer to Asian and Turkic people; regulation of territorial disputes about question of accessory of Orenburg; temporariness of the capital status of Orenburg to Kyrgyzia, in view of geographical distance of the city from the other regions of Autonomy and little representatives of title Kazakh ethnos. The author introduces for scientific use some documents of the State archive of the Orenburg Region in the process of research.

Keywords: Orenburg; capital; Orenburg province; Kirgiz (Kazakh) Autonomous Socialist Soviet Republic; Russian Soviet Federative Socialist Republic; Civil war; decree of Soviet power; Kirgiz (Kazakh) Autonomy; Kazakh statehood in $20^{\text {th }}$ century; history of Kazakhstan. 